Yet the Office of Research Integrity (ORI), the successor agency to the NIH's OSI, which (being an independent body in the office of the Secretary of the Deparment of Health and Human Services, HHS) was supposed to tidy up the errors and excesses of the OSI, has so far failed to release its final report on the case, and this despite a recent appeal filed with ORI by Imanishi-Kari's attorney, who is one step short of suing the government. The attorney, Bruce Singal, says that justice delayed is justice denied. In this case, there can be no arguing with that position.

Nor can anybody deny that the whole question of fraud in science is now in turmoil in the United States. OSI began life believing that its investigations could be conducted as if they were research projects aimed at discovering the best approximation to the truth. In doing so, it paid scant attention to people's right to due process - to cross-examine witnesses, to be legally represented and so on. But people so accused can appeal to the HHS Departmental Appeals Board, when standard court rules on evidence apply. That is the board that last year dismissed findings of misconduct against Ramashwar Sharma of Cleveland and Mikulas Popovic, Robert Gallo's right-hand man in the development of a blood test for the AIDS virus. (OSI's successor, ORI, then promptly dropped a case against Gallo himself.) Imanishi-Kari will be entitled to an appeals board hearing if ORI finds against her. Given the stakes, that is only just.

The lessons to be drawn from this state of affairs are far from clear, but two shine through. First, ORI and its predecessor are not suited to the task for which they were created. At best, they are too cumbersome. ORI should be abolished. Responsibility for identifying misconduct and for imposing sanctions on those responsible should rest with research institutions unless criminal activity is involved. NIH and other public agencies should be concerned only to ensure that client-institutions are vigilant in this regard. The US National Academy of Sciences and Institute of Medicine have recently issued a paper on research integrity in anticipation of a spring conference. For ORI, there is a simple duty. Before it goes out of business, it should speedily say where is stands on Imanishi-Kari. Justice requires no less.

\section{Zeal earns influence}

Philanthropist Mary Lasker was an extraordinary advocate for biomedical research.

Cliches apart, the death of Mary Woodard Lasker at 93 on 21 February in New York brings to a close a unique era in US biomedical politics. The widow of Albert Lasker, an early success in advertising, Mary Lasker made a fortune of less than $\$ 10$ million to a biomedical research foundation whose influence far outmatched its size.

Among Lasker's skills was the use of her elegant Manhattan house to cultivate the rich and powerful in US politics, beginning in the 1940s with the chairmen of congressional committees, whose individual powers far outstripped those of their present-day successors. Best known for the Lasker
Awards in research and medicine, and for successfully parlaying a few subsequent Nobel prizes into the doctrine that the first precedes the second, Lasker's most significant and lasting achievement lay in her extraordinary influence over the purse-strings of the US Congress.

She made fast friends of representatives and senators who devoted their careers to fostering the growth of the National Institutes of Health. Nearly single-handedly she led the billion-dollar "War on Cancer" in 1971, perhaps in the knowledge that the money would be spent on fundamental research in cell biology as well as more classic clinical investigation of drugs and radiation therapy. She believed that research had but one purpose: the cure of disease. She had style and, with her single-minded determination to make sick people well, became an American institution. Times have changed. Politics are no longer as simple as they were. Nobody is likely to take her place.

\section{French language wars}

The government in Paris is embarking on a misguided defence of the French language.

FRANCOPHILES everywhere will be alarmed by the bill on the use of the French language given outline approval last week by the French cabinet. If enacted, it will require, among others things, all scientific conferences in France to be held in French. Nature, which is planning two meetings in France this year (in October and December), has a vested interest in the bill's delay, but there is more than that to say.

M. Jacques Toubon, the minister of culture in Paris, is right to proclaim that there is a distinction between "international" and "universal"; French speakers are none the less international because of the language they speak, but would be diminished if compelled to speak some universal (and non-existent) Euroglot. Everybody, of course, agrees. Indeed, the rest of us would also be diminished if French were not the vivid language Toubon pleads for. But the question he raises goes deeper, and will not be put to rest by his hopes for machine translation: can French by compulsion serve the interests of France itself?

Sadly, the answer must be "NO". Two centuries of history have unfolded since the Revolution, and the world partly shaped by those great events is fashioned awkwardly for linguistic purists. The role of the English language in science (where it has only recently taken over from German) is a simple consequence of the growth of science in the United States since the Second World War and of the eagerness of researchers elsewhere to participate in and contribute to that endeavour. It is natural that those concerned should be resentful of this state of affairs; many have to learn a second language, and even then their contributions to the literature win less acclaim than those from familiar laboratories. But logic suggests the remedy is not to compel them to write or speak in their native languages, but to fund their own research enterprises so generously that the balance of linguistic advantage changes again. 